\title{
WATER-RETAINING POL YMER MITIGATES THE WATER DEFICIT IN Schinus terebinthifolia: PHOTOSYNTHETIC METABOLISM AND INITIAL GROWTH
}

\author{
Francisco A. Beltramin', Willian C. Silva ${ }^{1}$, Cleberton C. Santos ${ }^{1 *}$, \\ Silvana de P. Q. Scalon ${ }^{1}$, Maria do C. Vieira ${ }^{1}$
}

\author{
${ }^{1 *}$ Corresponding author. Universidade Federal da Grande Dourados/ Dourados - MS, Brasil. \\ E-mail: cleber_frs@yahoo.com.br | ORCID ID: https://orcid.org/0000-0001-6741-2622
}

KEYWORDS
Brazilian pink pepper,
Cerrado biome,
hydrogel,
physiological
plasticity.

\begin{abstract}
The use of water-retaining polymer (hydrogel) can mitigate the damage to the photosynthetic apparatus and increase the robustness of young plants under water deficit conditions. Thus, the aim of this study was to evaluate the effect of water-retaining polymer on the morphophysiological aspects of Schinus terebinthifolia Raddi submitted to water deficit. The studied water regimes were characterized by three plant irrigation management: 1) control: irrigated daily, 2) stress: water deficit (irrigation suspension) and 3) stress + hydrogel: water deficit + water-retaining polymer. The plants were submitted to irrigation suspension until photosynthesis approached zero $\left[1^{\text {st }} \mathrm{P} 0\right]$, followed by resumption of irrigation (REI) for 15 days. After REI, until recovery of photosynthetic rate of plants, the maintenance of irrigation of all plants for 90 days, characterizing the final recovery $\left(125^{\text {th }}\right.$ day of experiment). The photosynthetic rate reached values close to zero in plants under stress on the $20^{\text {th }}$ day of water restriction, whereas the plants in conditions with hydrogel did not show a decrease in leaf metabolism. Excluding intercellular $\mathrm{CO}_{2}$ concentration, physiological parameters were lower on ${ }^{1 \text { st }} \mathrm{P} 0$ in plants under water deficit grown without hydrogel than those in plants grown with hydrogel, but all plants showed physiological plasticity. The use hydrogel contributed to the maintenance of the photosynthetic capacity of S. terebinthifolia under water deficit.
\end{abstract}

\section{INTRODUCTION}

Tropical regions, particularly the Cerrado ecoregion, are characterized by different vegetation types and climatic seasonality that are caused by water fluctuations, leading to water deficit in certain periods of the year as a consequence of precipitation fluctuations (Fonseca et al., 2017). The low water availability in the soils of the Cerrado region can cause functional and metabolic damage to plants, such as stomatal closure, reduced Rubisco carboxylation efficiency, and increased intercellular $\mathrm{CO}_{2}$ concentration and production of reactive oxygen species (ROS), thereby compromising plant photosynthetic capacity and growth (França et al., 2017; Resende et al., 2019).

Adverse environmental conditions may hinder the survival success and initial establishment of plants in priority reforestation areas, during the recovery of degraded areas, and in integrated sustainable production systems. In this sense, it is necessary to establish the technologies that can mitigate the harmful effects of water deficit in young plants, because they need to maintain their physiological processes and production of photoassimilates, especially in the implementation phase.

It has been shown that the use of water-retaining polymers (hydrogels) contributes to the retention of water in the soil, making it available to plants in dry periods (Felippe et al., 2016; Silva et al., 2019), as well as improving aeration and the cation exchange capacity, and reducing nutrient leaching (Bartieres et al., 2016; Konzen et al., 2017). However, information on the ecophysiology of fruit tree species in the seedling phase associated with the use of hydrogels is scarce.

Among the species with bioecological potential for being cultivated in the Cerrado phytophysiognomy, Schinus terebinthifolia Raddi (Anacardiaceae), a pioneer plant species popularly known as the Brazilian pink pepper or red

\footnotetext{
${ }^{1}$ Universidade Federal da Grande Dourados/ Dourados - MS, Brasil.
}

Area Editor: Fernando França da Cunha

Received in: 3-9-2020

Accepted in: 7-29-2020 
pepper, is widely distributed in South America, including Brazil with its diverse biomes. In adult phase, this species can reach a height of 5 to $10 \mathrm{~m}$, and it bears small and reddish fruits, which are attractive to wild fauna (Oliveira Júnior et al., 2013; Viégas et al., 2018). The species has potential for use in integrated production systems and/or degraded areas with the goal of ecosystem service restoration.

The aim of this study was to evaluate the effect of water-retaining polymer on the morphophysiological aspects of $S$. terebinthifolia subjected to water deficit conditions. We intended to test the hypothesis that although water restriction reduces the efficiency of leaf metabolism, the addition of hydrogel to soil can mitigate damage to the photosynthetic apparatus and increase the tolerance of this plant species to water deficit in the initial growth phase for the recovery and enrichment of Cerrado areas.

\section{MATERIAL AND METHODS}

Ripe fruits of $S$. terebinthifolia (Access Registration No. A9CDAAE - CGEN-MMA, from 10/15/2018) were collected from matrices located in the Horto Medicinal Plants (22 $11^{\prime} 43.7^{\prime \prime S}$ and 54 $56^{\prime} 08.5^{\prime \prime} \mathrm{W}, 452 \mathrm{~m}$ a.s.l.), Federal University of Grande Dourados - UFGD, Dourados - MS, Brazil. After manual pulping, the seeds were immersed in sodium hypochlorite $(2 \%)$ for five minutes, and sowing was carried out in 72-cell expanded polystyrene trays filled with Tropstrato ${ }^{\circledR}$.

Sixty days after emergence, the seedlings were transplanted to $290 \mathrm{~cm}^{3}$ polyethylene tubes and placed in a nursery with $50 \%$ shade and daily irrigations until they reached an average height of $10 \mathrm{~cm}$, which occurred 30 days after transplanting. Then, they were transplanted to plastic pots filled with $10 \mathrm{~kg}$ of dry substrate consisting of Dystrophic Red Latosol + sand (3:1, v/v) with daily irrigations maintaining $70 \%$ of the water retention capacity (WRC) in the substrate for 30 days. This was the acclimatization period before the submission of plants to different water regimes.

The experiment was carried in a nursery with $30 \%$ shading and additional protection on the top and on the sides of the plastic cover with thickness of $150 \mu \mathrm{m}$, in order to provide protection from precipitation. The water regimes included three irrigation practices, i.e., three groups: 1) Control: plants irrigated daily, $70 \%$ of the WRC was maintained in the substrate according to Souza et al. (2002), 2) Stress: water deficit, i.e., suspension of irrigation, and the photosynthetic rate was monitored every two days until the values approached zero [ $\left.1^{\text {st }} \mathrm{P} 0\right]$, after which irrigation was resumed, and 3) Stress + hydrogel: water deficit + waterretaining polymer, the procedures were similar to those in the previous water regime.

The water-retaining polymer (Forth $\mathrm{Gel}^{\circledR}$ hydrogel), consisting of polyacrylic potassium polyacrylamide (soil conditioner - class $\mathrm{E}$; cationic exchange capacity $=53.22$ $\mathrm{cmol}_{\mathrm{c}} \mathrm{dm}^{3}$ ), was added to a container at a dose of $4 \mathrm{~g} \mathrm{~L}^{-1}$ of water and it remained in the container for 30 minutes, until the product had a gel appearance. Following this, $100 \mathrm{~mL}$ of the product was added at the time of seedling transplantation to each stress + hydrogel pot near the plant roots.

During the experimental period, the evaluations of morphophysiological characteristics were carried out in four periods: (1) T0 (beginning of the experiment: day zero, one day before suspending the irrigation of the corresponding treatments), (2) $1^{\text {st }}$ P0 (first time photosynthesis was close to zero: $20^{\text {th }}$ day), (3) REI (daily resumption of irrigation on substrate during 15 days after the $1^{\text {st }} \mathrm{P} 0: 20^{\text {th }}$ to $35^{\text {th }}$ day), this time when the plants under stress presented photosynthetic rate close to those of the control plants. After this period, all plants were irrigated daily for another 90 days, corresponding to the final recovery period (4) (REC), and the final evaluation was performed on the $125^{\text {th }}$ day of the experiment.

Irrigation was carried out according to the established water regimes, being those under daily irrigations, according to Souza et al. (2002), REI and REC were maintained under $70 \%$ of the WRC in the substrate; WRC of $100 \%$ in the substrate was determined using the water content retained after draining, and the WRC of $70 \%$ was obtained using a simple three rule as a function of weight. The pots were weighed on an analytical balance (0.001 $\mathrm{g}$ precision) and individualized irrigation was performed daily, with enough water to reach the preestablished of substrate weight.

The treatments were arranged in a subplot scheme, with water regimes allocated in the plots, and the evaluation periods in the subplots were conducted in a randomized block design, with four replications. Each experimental unit consisted of four pots with two plants in each pot. In each evaluation period, four plants were evaluated by repetition for non-destructive characteristics and one plant for destructive characteristics, and the following evaluations were carried out:

(a) Gas exchange: measured using fully expanded sheets, the rate of $\mathrm{CO}_{2}$ assimilation (photosynthesis): $A$ $\left(\mu \mathrm{mol} \mathrm{CO}_{2} \mathrm{~m}^{2} \mathrm{~s}^{-1}\right)$, intracellular $\mathrm{CO}_{2}$ concentration $-C_{\mathrm{i}}$ $\left(\mu \mathrm{mol} \mathrm{CO} \mathrm{Cm}^{2} \mathrm{~s}^{-1}\right)$, stomatal conductance $-g_{\mathrm{s}}\left(\mathrm{mol} \mathrm{H}_{2} \mathrm{O} \mathrm{m}\right.$ $\left.{ }_{2} \mathrm{~s}^{-1}\right)$, and transpiration $-E\left(\mathrm{mmol}^{-1} \mathrm{H}_{2} \mathrm{O} \mathrm{m} \mathrm{m}^{2} \mathrm{~s}^{-1}\right)$ were quantified using a portable LCIPro-SD photosynthesis meter (IRGA - Infra Red Gas Analyzer) (Model ADC BioScientific Ltd.). Measurements were made between 8 and 10 a.m. with photosynthetically active radiation of 865

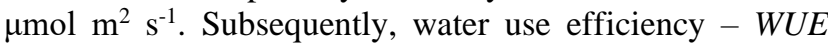
$\left(\mu \mathrm{mol} \mathrm{CO}_{2} / \mathrm{mmol} \mathrm{H}_{2} \mathrm{O}\right)$, Rubisco carboxylation $-A / C_{\mathrm{i}}$ $\left(\mu \mathrm{mol} \mathrm{m} \mathrm{m}^{-2} \mathrm{~s}^{-1} / \mu \mathrm{mol} \mathrm{mol}\right)$, and intrinsic water use $-{ }_{\mathrm{i}} W U E$ (mmol ${ }^{-1} \mathrm{H}_{2} \mathrm{O}$ ) were calculated as $A / E, A / C_{\mathrm{i}}$ and $A / g_{\mathrm{s}}$ ratios, respectively.

(b) Soil Plant Analyzer Development (SPAD) index: measured using a portable chlorophyll meter (Konica Minolta 502) in the morning (8 to 11 a.m.).

(c) Growth: measured by counting the number of fully expanded leaves, after which the plants were collected, separated into different plant parts, and the leaf area was determined using an area integrator (LI-COR, $3100 \mathrm{C}$ Area Meter, Nebraska, USA). The leaf limbs and roots were placed in an oven with forced air circulation at $60 \pm 5^{\circ} \mathrm{C}$ until a constant dry mass was obtained and weighed on a precision scale (0.0001 $\mathrm{g}$ precision).

(d) Physiological indices: calculated from the leaf area and dry biomass production data; leaf area to specific leaf area ratio was calculated as well (Benincasa, 2003).

The data were analyzed using analysis of variance (ANOVA), and the results that were significant by $\mathrm{F}$ test ( $p$ $<0.05)$, were used in comparing the means using Tukey test for water regimes and evaluation periods $(p \leq 0.05)$. Statistical analysis were performed using the SISVAR software (Ferreira, 2019). 


\section{RESULTS AND DISCUSSION}

The rates of $\mathrm{CO}_{2}$ assimilation $(A)$, stomatal conductance $\left(g_{\mathrm{s}}\right)$, and intercellular $\mathrm{CO}_{2}$ concentration $\left(C_{\mathrm{i}}\right)$ were influenced by the interaction between water regimes and evaluation periods. The photosynthetic rate $(A)$ reached values close to zero $\left({ }^{\text {st }} \mathrm{P} 0\right)$ in plants under stress $(1.01 \mu \mathrm{mol}$ $\mathrm{CO}_{2} \mathrm{~m}^{2} \mathrm{~s}^{-1}$ ) at 20 days of water restriction (Figure 1a). During this period, the plants subjected to daily irrigation (control) and stress + hydrogel maintained their $A$ values, indicating that the addition of hydrogel effectively contributed to the maintenance of water conditions in the plant, thereby preventing dehydration.
When performing the resumption of irrigation (REI), we observed an increase in $A$ in all plants, including those that were only subjected to stress, which maintained lower REI values when compared to the other plants in this period, obtaining values similar to the other plants only at the end of the experiment, thus extending the period required for recovery (REC). However, plants with added waterretaining polymer did not show a decrease in photosynthetic rate during irrigation suspension, but maintained values close to those of plants irrigated daily throughout the experimental period. The use of hydrogel favors the ability to maintain water in the soil as it can store high water volume, especially the excess water, and make it available to plants in dry periods (Silva et al., 2019).
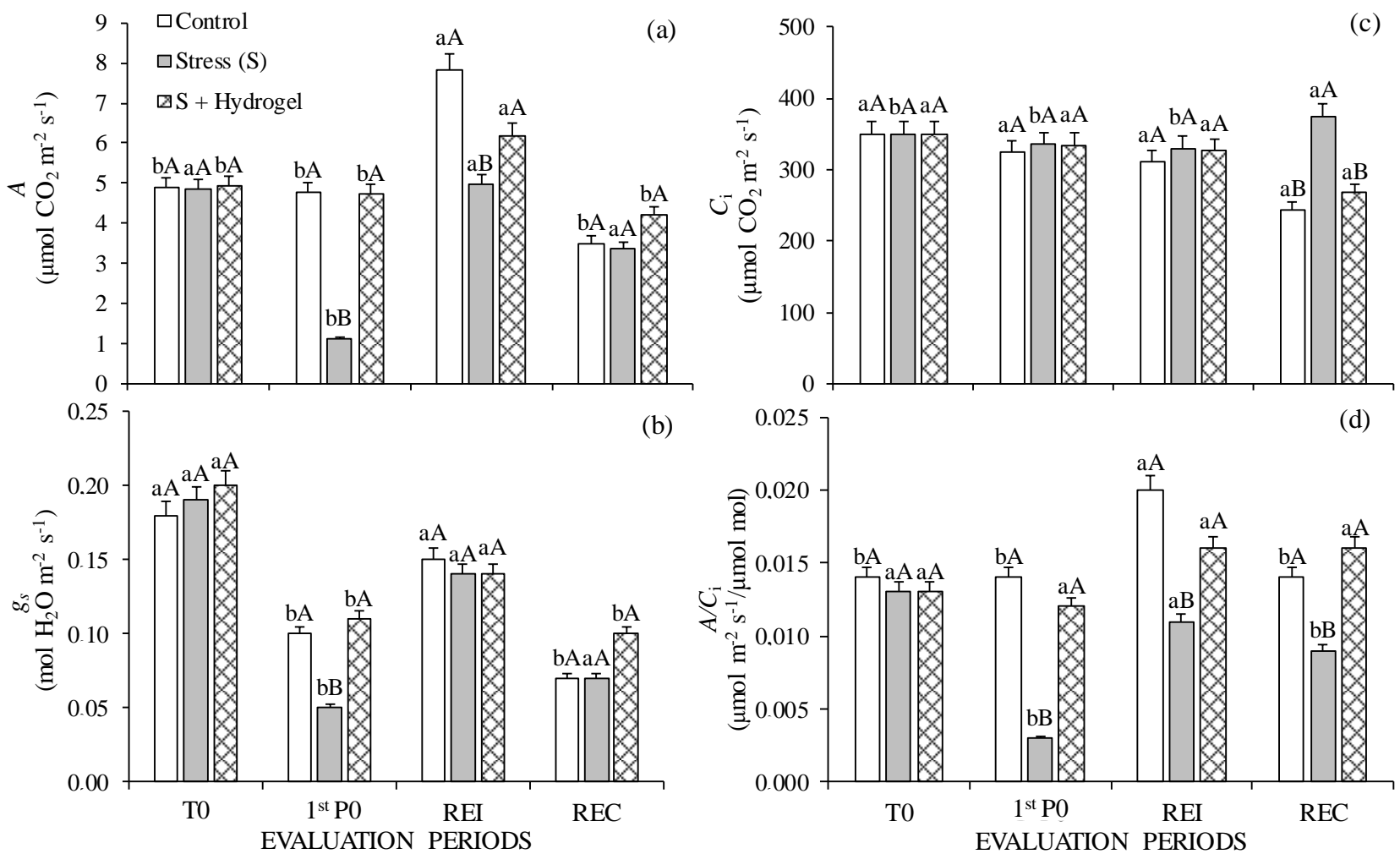

(c)

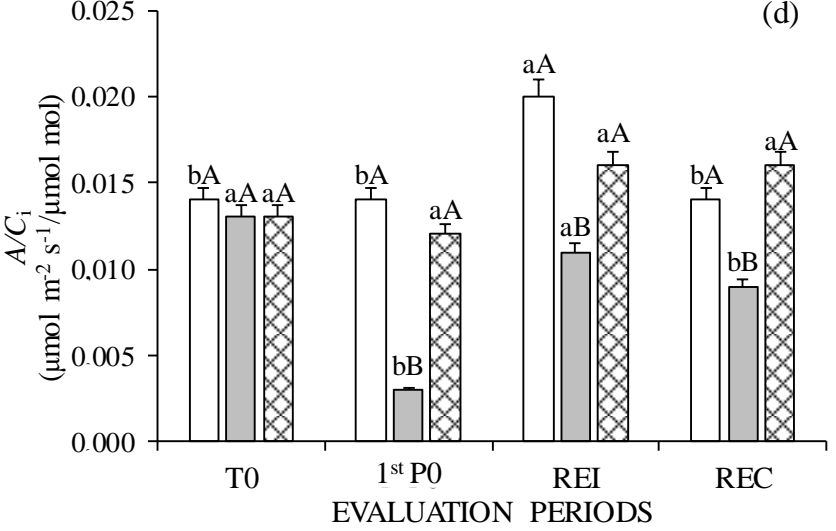

FIGURE 1. Variations in gas exchange characteristics in young plants of S. terebinthifolia under water regimes and evaluation periods. Photosynthesis $-A$ (a), stomatal conductance $-g_{\mathrm{s}}(\mathrm{b})$, intracellular $\mathrm{CO}_{2}$ concentration $-C_{\mathrm{i}}(\mathrm{c})$ and intrinsic efficiency of carboxylation $-A / C_{\mathrm{i}}(\mathrm{d})$. Lowercase letters compare the same water regime in the different evaluation periods, and uppercase the different water regimes on the same period (Tukey; $p<0.05$ ).

The $g_{\mathrm{s}}$ value was higher in T0 than in others evaluation periods, independent of the water regimes, as these plants were not yet subjected to stress conditions (Figure 1b). In the $1^{\text {st }} \mathrm{P} 0$, plants grown under stress conditions had lower $g_{\mathrm{s}}\left(0.05 \mathrm{~mol} \mathrm{H}_{2} \mathrm{O} \mathrm{m}^{-2} \mathrm{~s}^{-1}\right)$ than under control, with a tendency to reestablish their values after reirrigation. Lower $g_{\mathrm{s}}$ directly influence the decrease in $\mathrm{CO}_{2}$ entry into the substomatic chamber, limiting its assimilation capacity. In the REI period, $g_{\text {s }}$ values were higher than those in $1^{\text {st }} \mathrm{P} 0$, with no difference between the water regimes, whereas in REC, these values showed the same trend as $A$, that is, from the moment daily irrigation was started, the recovery capacity of the plants increased. This indicated physiological plasticity of the investigated plants.

Until the start of the REI period, the intercellular $\mathrm{CO}_{2}$ concentration remained similar under all water regimes. On the other hand, in REC, we recorded a higher $C_{\mathrm{i}}$ in plants under stress when compared to that in control plants, indicating lower efficiency of carboxylation in plants under these conditions, with the increase in $\mathrm{CO}_{2}$ in the tissues. However, when we observed the patterns of $C_{\mathrm{i}}$ (Figure 1c) and $A$ (Figure 1a), we found that the plants under stress had a photosynthetic rate similar to that of control plants, suggesting that other factors besides stomatal factors interfered with the photosynthetic efficiency of the investigated plants.

The decrease in water availability, influenced by the increase in abscisic acid, induces stomatal closure (França et al., 2017), reducing the assimilation and diffusion of $\mathrm{CO}_{2}$ (Ashraf \& Harris, 2013), as we observed in $S$. terebinthifolia. Conditions of low water availability result in a decrease in stomatal conductance (Wong et al., 1979). However, lower $g_{\text {s }}$ availability favors the optimization of water use by reducing transpiration rate (Kröber et al., 2015), as observed in the present study, in the plants in the $1^{\text {st }} \mathrm{P} 0$.

We observed lower values of $A / C_{\mathrm{i}}$ in plants under stress when compared to that in control plants in all periods of evaluation except at T0 (Figure 1d). The decrease in 
Rubisco carboxylation under low water availability ( $\left.1^{\text {st }} \mathrm{P} 0\right)$ is, among other factors, a consequence of lower $g_{\mathrm{s}}$, reflecting a higher $C_{\mathrm{i}}$. The increase in $C_{\mathrm{i}}$ is a reflection of lower Rubisco carboxylation, and this response can result in the damage to thylakoid membranes (Rejeb et al., 2014; Choudhury et al., 2017). When irrigation was resumed, the plants showed an increase in $A / C_{\mathrm{i}}$ similar to that in the other water regimes, including under stress, as this also increased the gas exchange in the same period, favoring the entry of $\mathrm{CO}_{2}$ and maximizing photosynthesis. In the REC, the plants showed a recovery capacity, but under stress, their recovery capacity was lower than that of the plants irrigated daily and lower than that of the plants under stress + hydrogel.
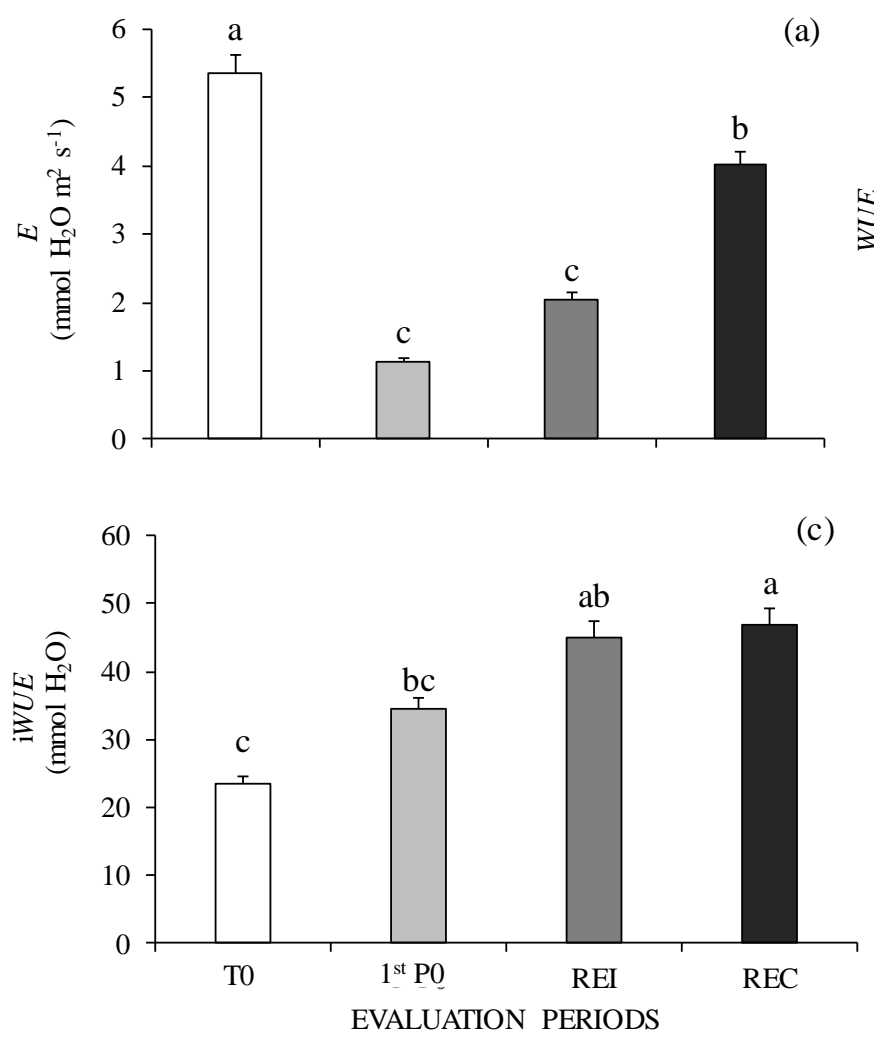

Leaf transpiration $(E)$ was influenced only by the evaluation periods, with the highest $E$ observed in plants at T0 $\left(5.35 \mathrm{mmol} \mathrm{H}_{2} \mathrm{O} \mathrm{m}^{-2} \mathrm{~s}^{-1}\right)$, and the lowest in plants at $1^{\text {st }}$ P0 (1.14 mmol $\mathrm{H}_{2} \mathrm{O} \mathrm{m}^{-2} \mathrm{~s}^{-1}$ ), which was not statistically different from these values in REI (Figure 2a). The reason for the lower $E$ value in $S$. terebinthifolia in the $1^{\text {st }} \mathrm{P} 0$ was the stomatal closure that was formed as a consequence of irrigation suspension, or what favors the reduction of water loss by tissue (Osakabe et al., 2014). After the $1^{\text {st }} \mathrm{P} 0$, there was a gradual increase in $E$, mainly in the REC (4.01 mmol $\mathrm{H}_{2} \mathrm{O} \mathrm{m}^{-2} \mathrm{~s}^{-1}$ ), demonstrating that this condition was overcome with irrigation recovery, as observed in the REI and REC.
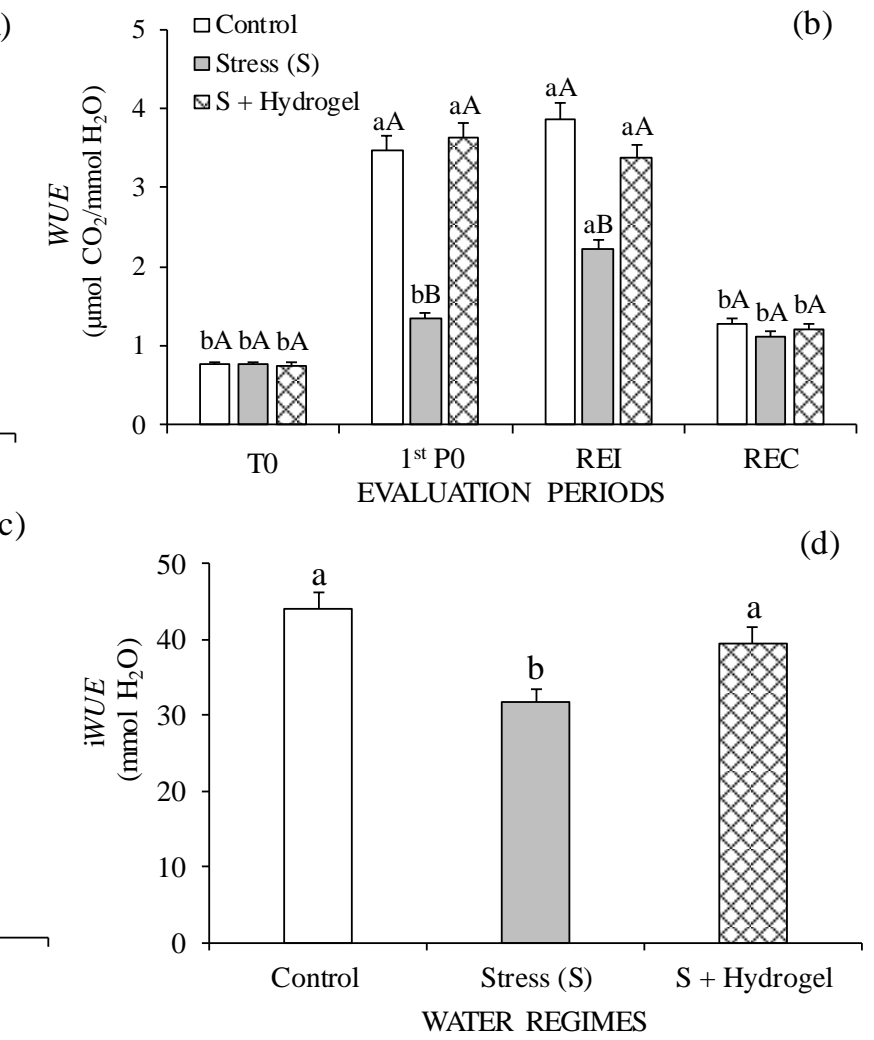

FIGURE 2. Variations in water use in young plants of $S$. terebinthifolia under differents water regimes and evaluation periods. Leaf transpiration $-E(\mathrm{a})$, water use efficiency $-W U E(\mathrm{~b})$ and intrinsic water use efficiency $-{ }_{\mathrm{i}} W U E(\mathrm{c}, \mathrm{d})$. (a-c-d) Equal letters in columns do not differ from each other (Tukey; $p<0.05$ ). (b) Lowercase letters compare the same water regime in the different evaluation periods, and uppercase the different water regimes on the same period (Tukey; $p<0.05$ ).

Water use efficiency (WUE) was influenced by the interaction between the factors under study (Figure 2b), and the irrigated plants kept under stress conditions with hydrogel showed higher values of $W U E$ in the $1^{\text {st }} \mathrm{P} 0$ when compared to those submitted to the deficit in function reduction of $E$ and $A$. Compared to control plants, we observed an increase in $W U E$ in plants under stress, and their WUE was lower when compared to those in plants in the other water regimes in the $1^{\text {st }} \mathrm{P} 0$ and REI. In the REC, we observed a decrease in relation to the other periods of evaluation, and therefore, the values were similar.

We found that ${ }_{i} W U E$ was influenced by the factors in isolation and increased during the evaluation periods (Figure 2c), with a lower value in plants under stress when compared to that in control plants (Figure 2d), which is a result of lower $g_{\mathrm{s}}$ reflecting lower $W U E$ and $A$. Therefore, the addition of hydrogels can contribute in maintaining the capacity of physiological processes under stress conditions such as intermittent water deficit. With regard to water regimes, results similar to ours were observed by Nunes et al. (2017) in S. terebinthifolia seedlings under intermittent water restriction, suggesting that the reduction of these characteristics $\left({ }_{i} W U E\right)$ indicate water saving.

The SPAD index, number of leaves, and leaf area were influenced by the interaction of the investigated factors. The SPAD index decreased in the $1^{\text {st }} \mathrm{P} 0$ in plants under water deficit (Figure 3a). The lowest SPAD index was observed in plants submitted to water deficit as a result of lower water availability in the substrate, and although they recovered after the resumption of irrigation, their SPAD index did not reach the values of the plants under continuous irrigation or those cultivated with hydrogel, supporting the hypothesis that water deficit is stressful for S. terebinthifolia.

Under conditions of low water status in the soil, cell turgor decreases and photosynthetic pigments degrade due 
to collapses in chloroplasts as a consequence of increase in carbohydrates and ROS, which causes oxidative damage (Zhang et al., 2014). Similarly, other species found in Cerrado phytophysiognomies, such as Hymenaea courbaril L. (Freitas et al., 2018) and Dipteryx alata Vogel. (Matos et al., 2018), also showed a reduction in chlorophyll content as a consequence of lower water availability in the soil.

(a)
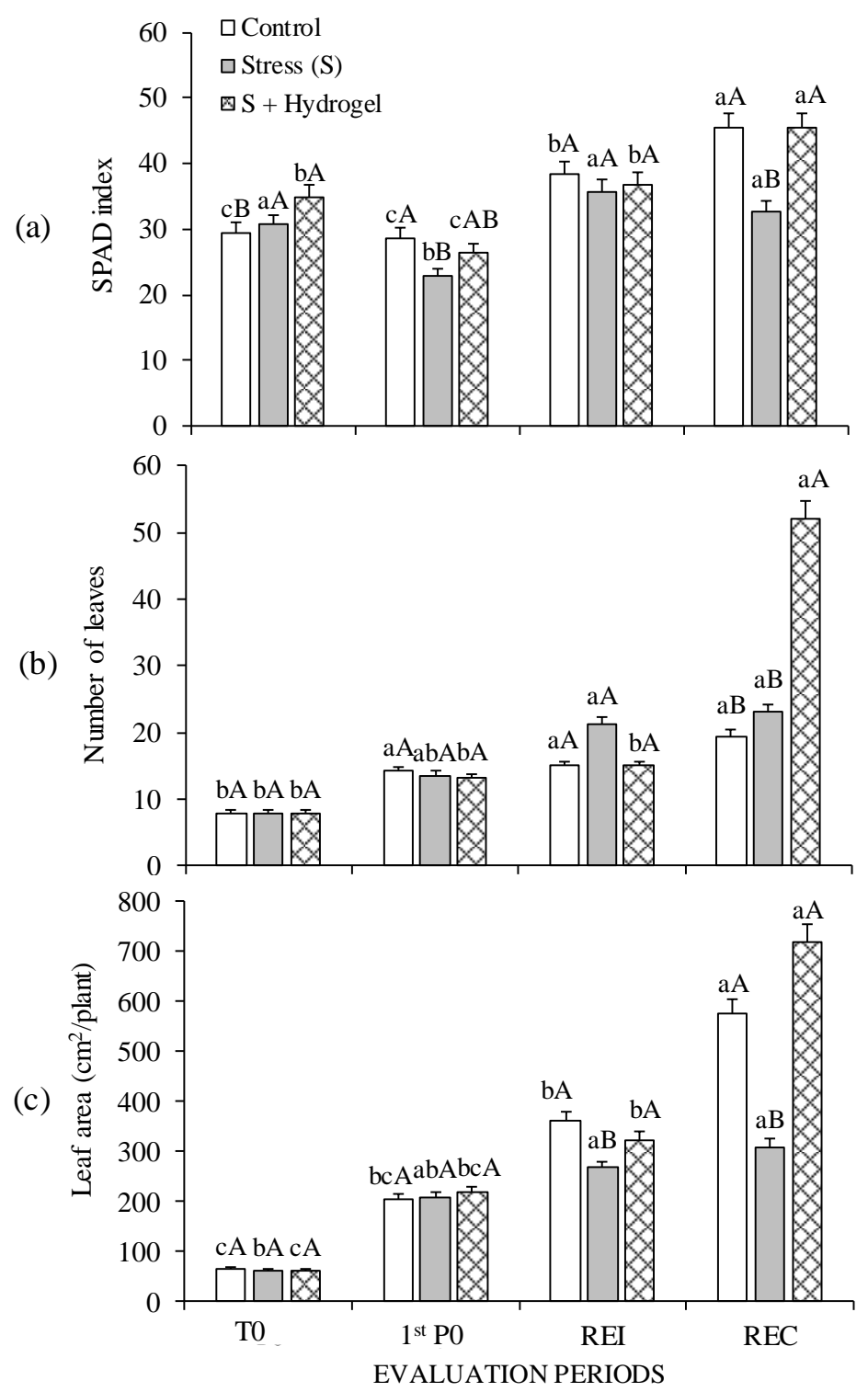

FIGURE 3. Variations in growth characteristics in young plants of S. terebinthifolia under water regimes and evaluation periods. Chlorophyll index - SPAD (a), number of leaves (b) and leaf area (c). Lowercase letters compare the same water regime in the different evaluation periods, and uppercase the different water regimes on the same period (Tukey; $p<0.05$ ).

The number of leaves did not vary in $\mathrm{T} 0$ and $1^{\text {st }} \mathrm{P} 0$ periods regardless of the water regime (Figure $3 \mathrm{~b}$ ). This pattern in T0 was a consequence of the standardization of seedlings (eight leaves) at the time of transplanting; however, under irrigation suspension, the investigated species showed a tolerance to this adverse condition in the $1^{\text {st }} \mathrm{P} 0$, possibly because of the fact that under reduced photosynthetic activity, it initially maintained the translocation of photoassimilates to the vegetative organs.

However, compared to the other water regimes, we observed an increase in the number of leaves in plants under water deficit in REI, demonstrating that the plants quickly responded to physiological stress (Freitas \& Silva, 2014). Nevertheless, in the REC, the plants showed a higher number of leaves in the stress + hydrogel treatment than in the other water regimes in the same period, which was possibly because of the prolonged effect of hydrogels on the soil, i.e., the polyacrylamide present on the hydrogel increased water availability for a longer period of time.

The largest leaf areas (LA) were observed in plants irrigated daily and under stress + hydrogel in the REI and REC (Figure 3c) because of the greater water availability in these conditions. The lower LA in plants subjected to stress may suggest they used strategies for reducing transpiration per unit area with the aim to maintain the integrity of photosynthetic machinery. These strategies have been reported in the literature as a protective response in several species, for example in the seedlings of Callophyllum brasiliense Cambess. (Reis et al., 2020); these plants also had a smaller leaf area when subjected to water deficit, similar to those observed in the present study. We found that $S$. terebinthifolia plants were tolerant to water deficit for several days ( $\left.1^{\text {st }} \mathrm{P} 0\right)$, maintaining a leaf area close to that of plants in the other treatments. However, the 
responses of plants to the stress conditions in the $1^{\text {st }} \mathrm{P} 0$ caused subsequent negative responses, that is, smaller LA even after the resumption of irrigation in plants grown without hydrogel.

The leaf dry mass was influenced only by the evaluation periods, in which the highest leaf dry mass values occurred over time (Figure 4a). These results were a consequence of the fact that even under conditions of water suspension and subsequent re-irrigation, the investigated plants optimized the available resources at the end of the experimental period, demonstrating the recovery capacity and increase in photoassimilates in the REC. Regarding the dry root mass, in the $1^{\text {st }} \mathrm{P} 0$, the plants under stress +

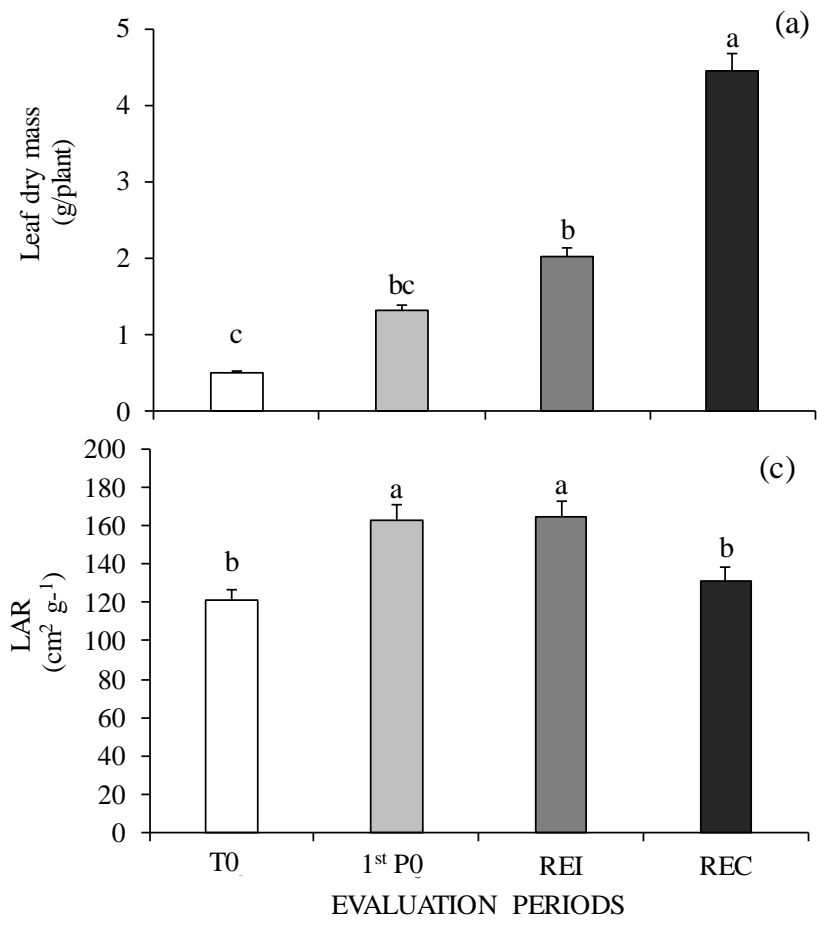

hydrogel showed higher dry root mass values when compared to those in the other water regimes (Figure 4b), demonstrating the beneficial effect of hydrogel, mainly because it was in close contact with the roots, thereby increasing the potential of the plant for nutrient and water absorption. During the REI, we observed an increase in root biomass in all water regimes. However, in the REC, the largest supply of root biomass occurred in plants irrigated daily and under stress + hydrogel, whereas those without the addition of hydrogel had lower root biomass values, indicating that the water deficit impaired the translocation of photoassimilates in roots even when the stress conditions were not present anymore.
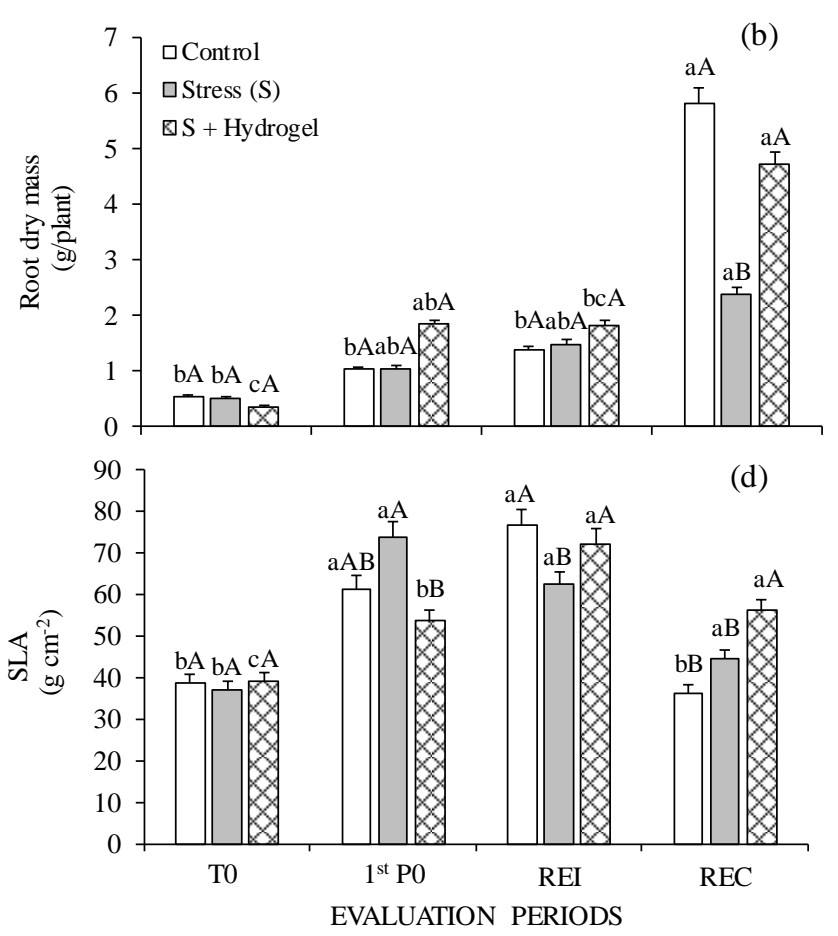

FIGURE 4. Variations in dry mass and physiological indexes characteristics in young plants S. terebinthifolia under different water regimes and evaluation periods. Leaf dry mass (a), root dry mass (b), leaf area ratio - LAR (c) and specific leaf area SLA (d). (a-c) Equal letters in columns do not differ from each other (Tukey; $p<0.05$ ). (b-d) Lowercase letters compare the same water regime in the different evaluation periods, and uppercase the different water regimes on the same period (Tukey; $p<0.05$ ).

The leaf area ratios were higher in plants in the $1^{\text {st }} \mathrm{P} 0$ and REI (Figure 4c), indicating that although the $S$. terebinthifolia seedlings had considerable LA (Figure 3c), they showed lower biomass accumulation in these two periods, because in the $1^{\text {st }} \mathrm{P} 0$, the plants were in stress conditions, and in the REI, the plants did not have sufficient time to fully recover the $A$ (Figure 1a) and biomass production in these cultivation conditions. The specific leaf area (SLA) was influenced by the interaction between water regimes and evaluation periods, presenting similar values in $\mathrm{T}_{0}$ for all treatments. In the $1^{\text {st }} \mathrm{P} 0$, the SLA of all treatments increased with increasing stress (Figure 4d). Compared to stress, plants under stress + hydrogel had higher SLA in the REI and REC.

The responses of leaf parameters to different water availabilities vary between different species. According to Campelo et al. (2015), the seedlings of Swietenia macrophylla (King), Handroanthus serratifolius (Vahl), and Handroanthus impetiginosa (Mart.) Matos showed lower SLA values when submitted to water deficit when compared to those in control plants, which was a different response from that observed in the present study for $S$. terebinthifolia. The variation in SLA can be explained by the increase in leaf thickness in response to water restriction, which was reflected in higher leaf biomass.

In general, it is worth noting that in addition to maintaining the water storage capacity in the soil, waterretaining polymers contribute to the mitigation of nutrient leaching (Navroski et al., 2015), especially when they are applied close to the roots. In this way, they increase the contact surface between roots and the rhizosphere, favoring nutrient intake and stabilizing plant metabolic processes, including $A, g_{\mathrm{s}}, A / C_{\mathrm{i}}$, and leaf morphological characteristics of $S$. terebinthifolia.

The use of water-retaining polymers has proved to be a promising practice for silvicultural activities in areas with irregular rainfall or inefficient irrigation system size, as it contributes to reduced costs of seedling replacement due to their greater survivability. 


\section{CONCLUSIONS}

Our results confirmed our hypothesis that the efficiency of leaf metabolism in S. terebinthifolia plants would be reduced under water restriction and that the addition of hydrogel to the soil would contribute to the maintenance of photosynthetic capacity and growth of this species, even under water deficit conditions, in addition to enhancing plant responses and biomass allocation in these conditions. In addition, we emphasized that $S$. terebinthifolia has the potential to recover gas exchange after stress periods, demonstrating its environmental resilience owing to its physiological plasticity.

\section{ACKNOWLEDGEMENTS}

To CNPq and CAPES, for granting scholarships and to FUNDECT, for financial support.

\section{REFERENCES}

Ashraf M, Harris PJC (2013) Photosynthesis under Stressful Environments: An Overview. Photosynthetica 51:163-190. DOI: http://dx.doi.org/10.1007/s11099-013-0021-6

Bartieres EMM, Carnevali NHS, Lima ESL, Carnevali TO, Mallmann V (2016) Hidrogel, calagem e adubação no desenvolvimento inicial, sobrevivência e composição nutricional de plantas híbridas de eucalipto. Brazilian Journal of Forestry Research 36(86):145-151. DOI: http://doi.org/10.4336/2016.pfb.36.86.990

Benincasa MMP (2003) Análise do crescimento de plantas (noções básicas). Jaboticabal, Funep, 41p.

Campelo DH, Lacerda CF, Sousa JA, Correia D, Bezerra AME, Araújo JDM, Neves ALR (2015) Trocas gasosas e eficiência do fotossistema II em plantas adultas de seis espécies florestais em função do suprimento de água no solo. Revista Árvore 39(5):973-883. DOI:

http://dx.doi.org/10.1590/0100-67622015000500020

Choudhury FK, Rivero RM, Blumwald E, Mittler R (2017) Reactive oxygen species, abiotic stress and stress combination. The Plant Journal 90:856-867. DOI: http://dx.doi.org/10.1111/tpj.13299

Felippe D, Navroski MC, Sampietro JA, Frigotto T, Albuquerque JA, Mota CS, Pereira MO (2016) Efeito do hidrogel no crescimento de mudas de Eucalyptus benthamii submetidas a diferentes frequências de irrigação. Floresta 46(2):215-225. DOI: http://dx.doi.org/10.5380/rf.v46i2.43920

Ferreira DF (2019) Sisvar: a computer analysis system to fixed effects split plot type designs. Revista Brasileira de Biometria 37(4):529-535. DOI:

http://dx.doi.org/10.28951/rbb.v37i4.450

Fonseca L, Roitman I, Jacobson TKB, Ogata RS, Solari RAF, Ribeiro RJC (2017) Viabilidade do hidrogel na recuperação de Cerrado sensu stricto com espécies nativas. Floresta e Ambiente 24:1-8. DOI:

http://dx.doi.org/10.1590/2179-8087.022716
França PHT, Silva ECA, Silva TC, Brasil A, Nogueira RJMC (2017) Análise fisiológica em mudas de guanandi (Calophyllum brasiliense Cambess.) submetidas ao déficit hídrico. Agropecuária Cientifica no Semiárido 13(4):264269. DOI: http://dx.doi.org/10.30969/acsa.v13i4.886

Freitas RS, Silva EC (2014) Respostas fisiológicas de mudas de Aspidosperma pyrifollium (Apocynaceae) à ciclos de suspensão de rega. Scientia Plena 14(5):1-12. DOI: http://dx.doi.org/10.14808/sci.plena.2018.051201

Freitas VDMB, Scalon SPQ, Dresch DM, Bastos SS, Souza APR (2018) Influence of exogenous application of abscisic acid on gas exchanges in Hymenaea courbaril L. (Fabaceae) seedlings subjected to water deficit. Floresta 48(2):163-172. DOI:

http://dx.doi.org/10.5380/rf.v48i2.53076

Konzen ER, Navroski MC, Friederichs G, Ferrari LH, Pereira MN, Fellipe D (2017) The use of hydrogel combined with appropriate substrate and fertilizer improve quality and growth performance of Mimosa scabrella Benth. seedlings. Cerne 23(4):473-482. DOI: http://dx.doi.org/10.1590/01047760201723042440

Kröber W, Plath I, Heklau H, Bruelheide H (2015) Relating stomatal conductance to leaf functional traits. Journal of Visualized Experiments 104:1-7. DOI: http://dx.doi.org/10.3791/52738

Matos FS, Freitas IAS, Santos VB, Venâncio DG, Silveira PS (2018) Initial growth of Dipteryx alata plants under water deficit. Revista Árvore 42(1):1-8. DOI: http://dx.doi.org/10.1590/1806-90882018000100003

Navroski MC, Araújo MM, Reininger LRS, Muniz MFB, Pereira MO (2015) Influência do hidrogel no crescimento e no teor de nutrientes das mudas de Eucalyptus dunnii. Floresta 45(2):315-328. DOI:

http://dx.doi.org/10.5380/rf.v45i2.34411

Nunes DP, Scalon SPQ, Dresch DM, Gordin CRB (2017) Photosynthetic and enzymatic metabolism of Schinus terebinthifolius Raddi seedlings under water deficit. Ciência e Agrotecnologia 41(6):1-7. DOI: http://dx.doi.org/10.1590/1413-70542017416005517

Oliveira Júnior LFG, Santos RB, Reis FO, Matsumoto ST, Bispo WMS, Machado LP, Oliveira LFM (2013) Fungitoxic effect of essential oil from aroeira (Schinus terebinthifolius Raddi) on Colletotrichum gloeosporioides. Revista Brasileira de Plantas Medicinais 15(1):150-157. DOI: http://dx.doi.org/10.1590/S1516-05722013000100021

Osakabe Y, Osakabe K, Shinozaki K, Tran LP (2014) Response of plants to water stress. Frontiers in Plant Science 5(86):1-8. DOI: http://dx.doi.org/10.3389/fpls.2014.00086

Reis LC, Scalon SPQ, Dresch DM, Foresti AC, Santos CC, Pereira ZV (2020) Chlorophyll- $a$ fluorescence as an indicator of water stress in Callophyllum brasiliense. Notulae Botanicae Horti Agrobotanici Cluj-Napoca 48(1):210-220. DOI: http://dx.doi.org/10.15835/nbha48111757 
Rejeb KB, Abdelly C, Savouré A (2014) How reactive oxygen species and proline face stress together. Plant Physiology and Biochemistry 80:278-284. DOI: https://doi.org/10.1016/j.plaphy.2014.04.007

Resende CF, Pacheco VS, Dornellas FF, Oliveira AMS, Freitas JCE, Peixoto PHP (2019) Responses of antioxidant enzymes, photosynthetic pigments and carbohydrates in micropropagated Pitcairnia encholirioides L.B. Sm. (Bromeliaceae) under ex vitro water deficit and after rehydration. Brazilian Journal of Biology 79(1):52-62. DOI: http://dx.doi.org/10.1590/1519-6984.175284

Silva WR, Salomão LC, Pereira DRM, Oliveira HFE, Pereira AIA, Cantuario FS (2019) Irrigation levels and use of hydro retainer polymer in greenhouse lettuce production. Revista Brasileira de Engenharia Agrícola e Ambiental 23(6):406-412. DOI: http://dx.doi.org/10.1590/18071929/agriambi.v23n6p406-412
Souza CC, Oliveira FA, Silva IF, Amorin Neto MS (2002) Avaliação de métodos de determinação de água disponível e manejo da irrigação em terra roxa sob cultivo de algodoeiro herbáceo. Revista Brasileira de Engenharia Agrícola e Ambiental 4(3):338-342. DOI: http://dx.doi.org/10.1590/S1415-43662000000300006

Viégas LB, Simões D, Lima KB, Silva MR (2018) Water management for Schinus terebinthifolius Raddi seedlings in degradable containers. Floresta e Ambiente 25(1):1-7. DOI: http://dx.doi.org/10.1590/2179-8087.008416

Wong SC, Farquhar IR, Farquhar GD (1979) Stomatal conductance correlates with photosynthetic capacity. Nature 282:424-426. DOI: https://doi.org/10.1038/282424a0

Zhang F, Zhang K, Du C, Xing Y, Yang L, Li Y (2014) Effect of drought stress on anatomical structure and chloroplast ultrastructure in leaves of sugarcane. Sugar Tech 17:41-48. DOI: https://doi.org/10.1007/s12355-014-0337-y 